\title{
REGIME CONSTITUCIONAL DO SERVIÇO POSTAL. LEGITIMIDADE DA ATUAÇÃO DA INICIATIVA PRIVADA.
}

\author{
LUÍS ROBERTO BARROSO*
}

I. A ORDEM ECONÔMICA NA CONSTITUIÇÃO DE 1988; - I.1. Pré-
compreensão do tema e princípios constitucionais; - I.2. A livre iniciativa como princípio fundamental do Estado brasileiro; - I.3. Modalidades de intervenção do Estado na ordem econômica: a) disciplina; b) fomento; e c) atuação direta; - I.4. O sistema constitucional da atuação direta do Estado na ordem econômica; - a) Prestação de serviços públicos: (i) serviços públicos inerentes e (ii) serviços públicos por opção político-normativa. Os serviços públicos por opção político-normativa podem ser ainda: 1 . delegados aos particulares de acordo com o art. 175 da Constituição; e 2. delegados aos particulares diretamente pela Constituição; - b) Desempenho de atividade econômica. Quanto à forma da atuação estatal: (i) monopolizada, (ii) não monopolizada e sob regime concorrencial. Quanto à necessidade da atuação estatal: (i) atividades obrigatórias por determinação constitucional, e (ii) atividades facultativas por opção político-normativa; - II. NATUREZA CONSTITUCIONAL DO SERVIÇO POSTAL; - II.1. O serviço postal não é serviço público;; - II.2. O serviço postal é atividade econômica não monopolizada, admitindo exploração concomitante pelos particulares; - Il.3. Quanto à necessidade da atuação estatal, o serviço postal é atividade obrigatória por determinação constitucional; quanto à forma de atuação estatal, o serviço postal é não monopolizado e sob regime concorrencial; - III. SITUAÇÃO CONSTITUCIONAL DA EMPRESA BRASILEIRA DE CORREIOS E TELÉGRAFOS - EBCT. A Constituição de 1988 não recepcionou o monopólio legal da Lei $n^{\circ} 6.538 / 78$. A EBCT desempenha atividade econômica obrigatória por determinação constitucional (CF, art. 21,X), não monopolizada e sob regime concorrencial; -IV. CONCLUSŌES

* Professor Titular de Direito Constitucional da Universidade do Estado do Rio de Janeiro. Master of Laws pela Universidade de Yale.

R. Dir. Adm.,

Rio de Janeiro, 222: 179-212, out./dez. 2000 
Trata-se de consulta acerca do regime jurídico aplicável aos serviços postais a partir da entrada em vigor da Constituição de 1988 , especialmente no que diz respeito à possibilidade da prestação de tais serviços por empresas particulares e à situação da Empresa Brasileira de Correios e Telégrafos-EBCT.

O tema praticamente não foi enfrentado pela doutrina, nem tampouco existem precedentes judiciais significativos a respeito. Nada obstante, inúmeras empresas e expressiva quantidade de empregados têm atuado no setor, de longa data, sem que se tenha procedido ao enquadramento jurídico da matéria.

O estudo que se segue cuida da atuação econômica do Estado, dos princípios que a regem e do conjunto de dispositivos constitucionais que disciplina os serviços públicos, a exploração da atividade econômica e a inserção dos serviços postais nesse contexto. A exposição encontra-se ordenada sistematicamente conforme o sumário acima apresentado.

\section{A ORDEM ECONÔMICA NA CONSTITUIÇÃO DE 1988}

\section{I.1. A pré-compreensão do tema é os princípios constitucionais}

1. A interpretação constitucional não é um exercício abstrato de busca de verdades universais e atemporais. Toda interpretação é produto de uma época, de um momento histórico, e envolve os fatos a serem enquadrados, o sistema jurídico, as circunstâncias do intérprete e o imaginário de cada um. A identificação do cenário, dos atores, das forças materiais atuantes e da posição do sujeito da interpretação constitui o que se denomina de pré-compreensão. ${ }^{\prime}$ Assinale-se, ainda, que o toque de singularidade da interpretação nesta virada de século em uma fase identificada como pós-positivismo ${ }^{2}$ - é a ascensão dos princípios e do papel que desempenham na revelação e construção do sentido das normas, sobretudo as de natureza constitucional. Abre-se, assim, breve tópico para a discussão desses dois aspectos - pré-compreensão e princípios constitucionais —, que são premissas doutrinárias relevantes das idéias desenvolvidas ao longo do texto.

1 Sobre o tema da pré-compreensão, v. Konrad Hesse, Escritos de derecho constitucional, 1983, p. 44: "El intéprete no puede captar el contenido da la norma desde un punto cuasi arquimédico situado fuera de la existencia histórica sino únicamente desde la concreta situación histórica em la que se encuentra, cuya piasmación há conformado sus hábitos mentales, condicionando sus conocimientos y sus pre-juicios".

2 Sobre o tema, vejam-se, dentre muitos. na doutrina nacional: Paulo Bonavides, Curso de direito constitucional, 1999, p. 237: Margarida Maria Lacombe Camargo, Hermenêutica e argumentaçāo, 1999 , p. 132. 
2. A despeito de seus discutíveis antecedentes - estigmatizados pelo patrimonialismo e pela apropriação privada - o Estado foi depositário de uma série de expectativas do constituinte de 1988. A verdade, todavia, é que o modelo de maior intervencionismo estatal não resistiu à onda mundial de esvaziamento do Estado como protagonista do processo econômico. Além da simbologia radical da queda do muro de Berlim, a verdade inafastável é que mesmo em países de tradição socialparticipativa, como Reino Unido e França, houve uma inequívoca redefinição do papel do Estado ${ }^{3}$.

3. No Brasil, o tema ainda vive momentos de efervescência política e jurídica. O Estado, seu tamanho e seu papel estão no centro do debate institucional e ainda mobilizam paixões antagônicas. Não é irrelevante observar, todavia, que a reforma do Estado (econômica, administrativa, previdenciária), nas suas dimensões constitucional e legislativa, foi aprovada com índices expressivos de apoio de opinião pública e parlamentar. Sem embargo de outras cogitações mais complexas e polêmicas, é fora de dúvida que a sociedade brasileira vem crescentemente rejeitando a idéia de um Estado volumoso e ativo no campo econômico.

4. As reformas econômicas brasileiras envolveram três transformações estruturais que se complementam mas não se confundem, e que podem ser assim sistematizadas: a) extinção de determinadas restrições ao capital estrangeiro (Emendas Constitucionais ns 6 , de 15/08/95, e 7, de 15/08/95), modificando o regime jurídico de temas relevantes como pesquisa e lavra de recursos minerais, aproveitamento de potenciais de energia elétrica e navegação de cabotagem; b) flexibilização dos monopólios estatais (Emendas Constitucionais ns 5, de 15/08/95; 8, de 15/08/95; e 9 , de 09/11/95), em serviços públicos como gás canalizado e telecomunicações e em atividades econômicas tidas como estratégicas, como pesquisa e lavra de petróleo; e c) desestatização (Lei 8.031, de 12/04/90, modificada pela Lei 9.491, de 9/09/97) levada a efeito por mecanismos como a (i) alienação, em leilão nas bolsas de valores, do controle de entidades estatais, e (ii) a concessão de serviços públicos a empresas privadas ${ }^{4}$.

3 V. Marcos Juruena Villeia Souto, Desestatização, privatização, concessões e terceirizações, 2000 , p. 4: "Na Inglaterra a privatização foi uma opção mais filosófica, consistente em definir que não cabe ao Estado produzir riqueza, gerar lucros e exercer atividades econômicas. Este papel deveria caber à iniciativa privada, que o faria com maior eficiência. (...) $O$ processo francês de privatização teve como uma de suas grandes preocupaçōes democratizar o patrimônio público constituído pelas estatais, através de um sistema de venda pulverizada das suas ações, permitindo ao pequeno poupador particular influir na condução dos negócios do país. (...) Tinha-se em mente, também, dar vida ao setor privado como força motriz do crescimento econômico, retirando o Estado do setor industrial competitivo".

4 Acrescente-se, em desfecho do levantamento aqui empreendido, que, além das Emendas Constitucionais $\mathrm{n}^{\circ \mathrm{s}} 5,6,7,8$ e 9, assim como das Leis $8.031 / 90$ e 9.491/97, os últimos anos foram marcados por uma fecunda produção legislativa em temas econômicos, que inclui diferentes setores, como: energia (Lei 9.247, de 26/12/96), telecomunicações (Lei 9.472, de 16/7/.97) e petróleo (Lei 
5. É possível detectar, assim, uma tendência nítida nas aspirações da sociedade brasileira. Tal tendência institucionalizou-se pelos mecanismos constitucionais próprios da emenda e da edição de legislação infraconstitucional. A concordância ou discordância em relação a este formato de Estado - fundado, essencialmente, no mercado e na livre concorrência - podem e devem ser manifestadas nas instâncias próprias. Não se pode, todavia, negar ou falsear uma ordem legitimamente em vigor. É preciso evitar, aqui, uma das patologias crônicas da hermenêutica constitucional no Brasil: a interpretação retrospectiva, pela qual se procura interpretar o texto novo de maneira a que ele não inove nada, mas, ao revés, fique tão parecido quanto possível com o antigo. ${ }^{5}$ Com argúcia e espírito, Barbosa Moreira estigmatiza a equivocidade desta postura:

"Põe-se ênfase nas semelhanças, corre-se um véu sobre as diferenças e conclui-se que, à luz daquelas, e a despeito destas, a disciplina da matéria, afinal de contas, mudou pouco, se é que na verdade mudou. É um tipo de interpretação em que o olhar do intérprete dirige-se antes ao passado que ao presente, e a imagem que ele capta é menos a representação da realidade que uma sombra fantasmagórica." 6

\section{OS PRINCÍPIOS CONSTITUCIONAIS}

6. O ponto de partida do intérprete há de ser sempre os princípios constitucionais, que são o conjunto de normas que espelham a ideologia da Constituição, seus postulados básicos e seus fins. Dito de forma sumária, os princípios constitucionais são as normas eleitas pelo constituinte como fundamentos ou qualificações essenciais da ordem jurídica que institui. A atividade de interpretação da Constituição deve começar pela identificação do princípio maior que rege o tema a ser apreciado, descendo do mais genérico ao mais específico, até chegar à formulação da regra concreta que vai reger a espécie.

7. Aos princípios cabe (i) embasar as decisões políticas fundamentais, (ii) dar unidade ao sistema normativo e (iii) pautar a interpretação e aplicação de todas as normas jurídicas vigentes. Os princípios irradiam-se pelo sistema normativo, repercutindo sobre as demais normas constitucionais e infraconstitucionais. Conforme sua amplitude e influência, classificam-se como fundamentais, gerais e setoriais ${ }^{7}$. Pois

9.478, de 6/8/97), com a criação das respectivas agências reguladoras; modernização dos portos (Lei 8.630, de 25/2/93) e defesa da concorrência (Lei 8.884, de 11/6/94); concessōes e permissões (Leis 8.987, de 13/2/95 e 9.074, de 7/7/95), para citar alguns exemplos.

5 Sobre este e outros aspectos da interpretação constitucional, vide Luís Roberto Barroso, Interpretação e aplicação da Constituição, 1999.

6 José Carlos Barbosa Moreira, $O$ Poder Judiciário e a efetividade da nova Constituição, in Revista Forense, vol. 304, p. 152.

7 Princípios constitucionais fundamentais são aqueles que contêm as decisões estruturais do Estado, as opções essenciais do constituinte na esfera política, econômica e social; princípios 
bem: no direito constitucional brasileiro a livre iniciativa figura como princípio fundamental e como princípio geral, na dicção do art. $1^{\circ}$, IV, e do art. 170, caput:

“Art.1. A República Federativa do Brasil (...) tem como fundamentos:

IV - os valores sociais do trabalho e da livre iniciativa;"

"Art. 170. A ordem econômica, fundada na valorização do trabalho humano $e$ na livre iniciativa (...)"

8. É, portanto, à luz desses elementos principiológicos que se deve promover o equacionamento jurídico da matéria.

\section{I.2. A livre iniciativa como princípio fundamental do estado brasileiro}

9. Do ponto de vista jurídico, o princípio da livre iniciativa pode ser decomposto em alguns elementos que lhe dão conteúdo, todos eles desdobrados no texto constitucional. Pressupõe ele, em primeiro lugar, a existência de propriedade privada, isto é, de apropriação particular dos bens e dos meios de produção $\left(\mathrm{CF}\right.$, arts. $5^{\circ}$, XXII e 170, II). De parte isto, integra, igualmente, o núcleo da idéia de livre iniciativa a liberdade de empresa, conceito materializado no parágrafo único do art. 170 , que assegura a todos o livre exercício de qualquer atividade econômica, independentemente de autorização, salvo nos casos previstos em lei. Em terceiro lugar situa-se a liberdade de lucro, lastro para a faculdade de o empreendedor estabelecer os seus preços, que hão de ser determinados, em princípio, pelo mercado, por meio de "livre concorrência", locução abrigada no art. 170, IV. Por fim, é da essência do regime de livre iniciativa a liberdade de contratar, decorrência lógica do princípio da legalidade, fundamento das demais liberdades, pelo qual ninguém será obrigado a fazer ou deixar de fazer alguma coisa senão em virtude de lei (CF, art. $5^{\circ}$, II).

10. Note-se, todavia, que o princípio da livre iniciativa, como intuitivo, não é absoluto, devendo ser ponderado com outros valores e fins públicos previstos no próprio texto da Constituição, como, por exemplo, o dever do Estado de promover o bem de todos (art. $3^{\circ}$, IV) e a justiça social (art. 170, caput). ${ }^{8}$ Sujeita-se, assim, à

constitucionais gerais são especificações dos princípios fundamentais, com menor grau de abstração, ensejando a tutela imediata das situações que contemplam, dentre os quais se situa a legalidade (CF, art. $\left.5^{\circ}, \mathrm{II}\right)$, a isonomia (CF, art. $5^{\circ}$, caput) e a liberdade de trabalho (CF, art. $\left.5^{\circ}, \mathrm{XIII}\right)$; e princípios constitucionais setoriais ou especiais são aqueles que presidem um específico conjunto de normas afetas a determinado tema, capítulo ou título da Constituição, como o sistema tributário, a Administração Pública ou a ordem econômica.

8 Sobre a teoria dos princípios e a ponderação de valores, veja-se Robert Alexy, Teoria de los derechos fundamentales, 1997, p. 83: Daniel Sarmento, A ponderação de interesses na Constituiçāo Federal, 2000, p. 41 e ss. e Heinrich Scholler, $O$ principio da proporcionalidade no direito constitucional e administrativo da Alemanha, Trad. Ingo Wolfgang Sarlet, 1999, Revista Interesse Público $n^{\circ} 2$, p. 93 e ss.. 
atividade reguladora e fiscalizadora do Estado voltadas à implementação das normas constitucionais destinadas a neutralizar ou reduzir as distorções que possam advir do abuso da liberdade de iniciativa. Diogo de Figueiredo Moreira Neto sistematizou o tema com apuro:

"O princípio da liberdade de iniciativa tempera-se pelo da iniciativa suplementar do Estado; o princípio da liberdade de empresa corrige-se com o da definição da função social da empresa; o princípio da liberdade de lucro, bem como o da liberdade de competição, moderam-se com o da repressão do abuso de poder econômico; o princípio da liberdade de contratação limita-se pela aplicação dos princípios de valorização do trabalho e da harmonia e solidariedade entre as categorias sociais de produção; e, finalmente, o princípio da propriedade privada restringe-se com o princípio da função social da propriedade."

11. A propósito, deve-se registrar o fato de que o tratamento constitucional da livre iniciativa no Texto de 1988 traz uma visão diversa da ordem econômica e do papel do Estado, em contraste com os modelos anteriores. ${ }^{10}$ Já não se concede mais, como fazia a Carta de $1967 / 69,{ }^{11}$ ampla competência na matéria ao legislador ordinário, ao qual era reconhecida até mesmo a possibilidade de instituir monopólios estatais. A experiência demonstrou que tal faculdade distorceu o caráter subsidiário e excepcional da atuação estatal na economia, propiciando a criação de centenas de empresas estatais. Em setembro de 1981, recenseamento oficial arrolava a existência, apenas no plano federal, de 530 pessoas jurídicas públicas de caráter econômico, inclusive autarquias, fundações e entidades paraestatais. ${ }^{12}$

12. A Carta de 1988 manteve a referência já tradicional à livre iniciativa, no capítulo dedicado à ordem econômica, mas promoveu-a a princípio fundamental do Estado brasileiro, dando-lhe novo status constitucional ${ }^{13}$. Além disso, disciplinou exaustivamente as formas de intervenção do Estado no domínio econômico, fixando

9 Diogo de Figueiredo Moreira Neto, Ordem econômica e desenvolvimento na Constituição de 1988,1989 , p. 28.

10 Alguns autores, a fim de ilustrar a afirmação de que a Constituição de 1988 restringiu, mais que as anteriores, a possibilidade de intervenção do Estado na economia, ressaltam que o Texto não mais fala em "intervenção", mas sim em "atuação". Nesse sentido: Hely Lopes Meirelles, Direito administrativo brasileiro, 1993, p. 545, e Eros Roberto Grau, A ordem econômica na Constituiçāo de 1988. Interpretação e crítica. 1990, p. 138.

11 "Art. 163. São facultados a intervenção no domínio econômico e o monopólio de determinada indústria ou atividade, mediante lei federal, quando indispensável por motivo de segurança nacional ou para organizar setor que não possa ser desenvolvido com eficácia no regime de competição e de liberdade de iniciativa, assegurados os direitos e garantias individuais."

12 Caio Tácito, $O$ retorno do pêndulo: serviço publico e empresa privada. $O$ exemplo brasileiro. Revista de Direito Administrativo ${ }^{\circ} 202$, p.l e ss..

13 Geraldo Vidal, A ordem econômica in A Constituição brasileira - 1988 - interpretações, 1988, p. 383. 
os limites da ação legislativa na matéria - em qualquer caso excepcional ${ }^{14}$-, na qual não se inclui a possibilidade de criar novos monopólios. Qualquer restrição ao princípio precisa estar fundada na própria Constituição.

13. Investigou-se, assim, o sentido e o alcance do princípio da livre iniciativa na Constituição, à vista da circunstância de ser ele o vetor interpretativo a ser seguido e ao qual se deve dar a devida dimensão de peso na ponderação com outros valores constitucionais. Em seguida serão examinadas as possibilidades legítimas de atuação econômica do Estado.

\section{I.3. Modalidades de intervenção do Estado na ordem econômica}

14. A sistematização doutrinária das formas de intervenção do Estado na economia varia conforme o critério adotado. Há autores que se referem a intervenção $(a)$ regulatória, $(b)$ concorrencial, $(c)$ monopolista e $(d)$ sancionatória $^{15}$. Outros classificam-na em $(a)$ poder de polícia, $(b)$ incentivos à iniciativa privada e $(c)$ atuação empresarial ${ }^{16}$. Nessa linha, é possível identificar três mecanismos de intervenção estatal no domínio econômico: a disciplina, o fomento e a atuação direta.

15. O Poder Público interfere com a atividade econômica, em primeiro lugar, traçando-lhe a disciplina, e o faz mediante a edição de leis, de regulamentos e pelo exercício do poder de polícia. De outra parte, o Estado interfere no domínio econômico por via do fomento, isto é, apoiando a iniciativa privada e estimulando (ou desestimulando) determinados comportamentos, por meio, por exemplo, de incentivos fiscais ou financiamentos públicos. ${ }^{17}$ Por fim, o Estado interfere, ainda, na ordem econômica, mediante atuação direta. Aqui, todavia, é necessário distinguir duas possibilidades: (a) a prestação de serviços públicos; e (b) a exploração de atividades econômicas.

16. Os serviços públicos podem ser prestados diretamente, pelos órgãos despersonalizados integrantes da Administração, ou indiretamente, por entidades com personalidade jurídica própria. Na prestação indireta, abrem-se duas possibilidades: pode o Estado constituir pessoas jurídicas públicas (autarquias e fundações públicas) ou privadas (sociedades de economia mista e empresas públicas) e,

14 Como registra o art. 173 da Constituição, a atuação do Estado como agente econômico será sempre excepcional. mesmo quando não exclua a participação dos particulares e se processe em regime concorrencial.

15 Diogo de Figueiredo Moreira Neto. Curso de direito administrativo, 1996, p. 365.

16 Celso Antonio Bandeira de Mello, Curso de direito administrativo, 1996, p. 434-5.

17 Luiz Carlos Bresser Pereira. Cidadania e res publica: a emergência dos direitos republicanos, Revista de Direito Administrativo ${ }^{\circ} 208$, p.147 e ss.. Em interessante estudo, o autor identifica como direito republicano o direito a que os recursos públicos sejam aplicados no interesse $\mathrm{e}$ benefício de toda a coletividade. e não de alguns grupos privados. Embora nem sempre se concorde com os exemplos utilizados pelo autor (que. por vezes, não distingue entre direitos legitimamente adquiridos e interesses privados ilegítimos), o trabalho merece registro. 
mediante lei ( $\mathrm{CF}$, art. 37, XIX), outorgar a tais entes a prestação do serviço público, seja de educação, água, eletricidade ou qualquer outro. Ou pode, por outro lado, delegar à iniciativa privada, mediante contrato ou outro ato negocial, a prestação do serviço ${ }^{18}$. Serve-se aí o Estado de figuras jurídicas como a concessão e a permissão. O caput do art. 175 provê sobre a matéria e será objeto de exame pouco mais à frente.

17. A exploração da atividade econômica, à sua vez, não se confunde com a prestação de serviços públicos, quer por seu caráter de subsidiariedade, quer pela existência de regras próprias e diferenciadas. De fato, sendo o princípio maior o da livre iniciativa, somente em hipóteses restritas e constitucionalmente previstas poderá o Estado atuar diretamente, como empresário, no domínio econômico. Tais exceções se resumem aos casos de:

a) imperativo da segurança nacional (CF, art. 173, caput);

b) relevante interesse coletivo ( $\mathrm{CF}$, art. 173, caput);

c) monopólio outorgado à União (e.g., CF, art. 177).

18. O tema é aprofundado no capítulo que se segue.

\section{I.4. O sistema constitucional da atuação direta do Estado na ordem econômica}

a) A prestação de serviços públicos

19. A noção de serviço público não é estável nem precisa, de modo que nem sempre é fácil distingui-lo, do ponto de vista material, de uma atividade econômica pura $^{19}$. Justo ao contrário, a moderna doutrina reconhece que seus contornos variam em função do tempo e do espaço, flutuando "ao sabor das necessidades e contingências políticas, econômicas, sociais e culturais de cada comunidade, em cada momento histórico" ${ }^{20}$. A diversidade histórica e geográfica das funções estatais conduz à impossibilidade de se utilizarem conceitos teóricos rígidos e imutáveis ${ }^{21}$. Nada obstante, saber se determinada atividade constitui ou não serviço público é de fundamental importância para determinar-se a disciplina jurídica a ela aplicável.

20. O serviço público é tradicionalmente conceituado como atividade exercida pelo Estado, a fim de satisfazer necessidades coletivas, sob regime jurídico de direito

18 Salvo no caso dos serviços de educaçāo, saúde e previdência privada, que a Constituição delega diretamente aos particulares. Para o desempenho dessas atividades, a iniciativa privada deverá obter apenas uma licença prévia, ato vinculado da Administração. Sobre esse ponto se voltará no item 1.4 .

19 Eros Roberto Grau, A ordem econômica na Constituição de 1988. Interpretação e crítica, 1990 , p. 132, onde se utiliza a expressão "atividade econômica em sentido estrito".

20 Hely Lopes Meirelles, Direito Administrativo brasileiro, 1993, p. 294 e Fernando Herren Aguillar, Controle social de serviços públicos, 1999, p. 112/117.

21 Diogo de Figueiredo Moreira Neto, Mutaçōes do direito administrativo, 2000, p. 124 e ss.. 
público ${ }^{22}$. Identificam-se nessa conceituação seus três elementos característicos: o elemento subjetivo (o serviço é prestado pelo Estado), um elemento material (o serviço se destina à satisfação concreta de necessidades coletivas) e um elemento formal (o serviço se submete a regime jurídico público).

21. Esse conceito, entretanto, bem como a verificação rigorosa de seus elementos, tem sofrido flexibilizações com o tempo, razão pela qual alguns autores chegam a falar em "crise da noção de serviço público" ${ }^{23}$. Com efeito, a primeira modificação observada nos critérios comumente utilizados para conceituá-lo operou-se no âmbito subjetivo. É que, embora os serviços públicos continuem sendo titularizados pelo Estado, a sua efetiva prestação deixou de ser exclusividade dos órgãos públicos. De fato, a execução de muitos serviços passou a ser transferida a pessoas jurídicas especificamente criadas pelo Estado para esse fim, e também a particulares, através de contratos de concessão ou permissão. Assim, o elemento subjetivo do serviço público teve de ser adaptado para englobar não só a prestação direta pelo Estado, mas também por qualquer outro ente ao qual se transferisse o encargo, por outorga legal ou delegação contratual ${ }^{24}$.

22. A Constituição de 1988 assimilou essa concepção mais abrangente quanto ao aspecto subjetivo do serviço público, especialmente no que diz respeito à delegação a particulares, afirmando a possibilidade de concessão ou permissão da execução do serviço tanto na regra geral inscrita em seu art. 175, como em todas as ocasiões em que cuidou dos serviços públicos, sejam federais (art. 21, XI e XII), estaduais (art. 25, § $2^{\circ}$ ) ou municipais (art. 30, V). Confira-se a dicção dos dispositivos referidos:

“Art. 175. Incumbe ao Poder Público, na forma da lei, diretamente ou sob regime de concessão ou permissão, sempre através de licitação, a prestação de serviços públicos."

22 José Cretella Júnior, Administraçāo indireta brasileira, 1980, p. 55.

23 Sobre o tema, confiram-se: Celso Antônio Bandeira de Mello, Natureza e regime juridico das autarquias, 1968, pp. 137 e ss.; Diogo Figueiredo Moreira Neto, Mutaçōes do Direito Administrativo. 2000, p. 124 e Maria Sylvia Zanella de Pietro, Direito administrativo, 1999, pp. 96 e ss..

24 A propósito das modificações no aspecto subjetivo do serviço público. escreve Diogo de Figueiredo Moreira Neto, Mutaçōes do direito administrativo, 2000, p. 126: "Hoje, basta que o Estado preste, por qualquer de seus órgãos, ou apenas assegure sua prestação, seja através de delegatários legais, sem interferência de qualquer órgão ou entidade da Administração Pública, seja, como classicamente se tem entendido, através de delegatários administrativos. Diversificam-se e enriquecem-se, assim, as modalidades de prestação de serviços públicos com a crescente e multifária colaboração do setor privado, necessitando-se, em consequiência, de novos conceitos e atualizadas sistematizaçōes. Com efeito, tornou-se necessário enfrentar uma bateria de recentes questionamentos que estāo atingindo, em extensão e profundidade, o conceito de serviços públicos: como se configura a gestão estatal? Como se caracterizam os serviços públicos independentes do aparelho da Administração Pública? Que tipo de gestão se compatibiliza com as diferentes modalidades de serviços públicos? Quais as modalidades de transferência de gestão de serviços públicos admissíveis? Quais os limites de transferibilidade da gestão de serviços públicos? Quais os instrumentos de controle dos serviços transferidos? etc.". 
"Art. 21. Compete à União:

(...)

$X I$ - explorar, diretamente ou mediante autorização, concessão ou permissão, os serviços de telecomunicações (...)

$X I I$ - explorar, diretamente ou mediante autorização, concessão ou permissão (...)"

“Art. 25. (...)

$\S 2^{\circ}$. Cabe aos Estados explorar diretamente, ou mediante concessão, os serviços locais de gás canalizado (...)"

“Art. 30. Compete aos Municípios:

(...)

$V$ - organizar e prestar, diretamente ou sob regime de concessão ou permissão, os serviços públicos de interesse local, incluido o de transporte coletivo, que tem caráter essencial."

23. O elemento formal também sofreu alguns temperamentos, até mesmo em consequiência da participação de particulares na prestação de serviços públicos, não se considerando mais adequado afirmar a existência de um regime puramente de direito público. De toda sorte, ainda é o elemento formal quem dá a nota jurídica que caracteriza a noção de serviço público pois, nada obstante a tentativa de harmonizar os interesses público e privado envolvidos, o regime jurídico aplicado à prestação dos serviços públicos apresenta elementos inconfundíveis, de natureza pública, que o diferencia dos demais. Celso Antônio Bandeira de Mello enumera alguns desses elementos nos seguintes termos:

“A estrita submissão ao princípio da legalidade, a utilização de técnicas autoritárias, expressivas da soberania, de que são manifestações a possibilidade de constituir obrigações por ato unilateral, a presunção de legitimidade dos atos praticados, a auto-executoriedade deles, bem como sua revogabilidade $e$ unilateral declaração de nulidade, a continuidade necessária das atividades havidas como públicas, donde - no plano do serviço público - a impossibilidade do concessionário invocar a exceptio non adimpleti contractus para eximir-se da regular continuidade de seu desempenho, a rigorosa obediência ao princípio da isonomia etc." 2 .

24. O mais grave traço da "crise" da noção de serviço público, todavia, diz respeito ao seu elemento material. Tradicionalmente, o serviço público era compreendido como aquele que atendia a uma necessidade coletiva, que só poderia ser suprida pela ação estatal. O serviço público era, portanto, aquela atividade que, em determinado momento histórico, encontrava-se vinculada à própria noção de Estado,

25 Celso Antônio Bandeira de Mello, Curso de direito administrativo, 1997, p. 426. 
decorria de sua soberania. Não se cogitava que ela pudesse ser prestada por outrem que não o Estado.

25. Essas noções mudaram significativamente ao longo do século XX, na medida em que o Estado, sob o rótulo de prestação de serviço público, passou a assumir papéis ativos na ordem econômica e social, incumbindo-se de tarefas que antes eram reservadas à iniciativa privada. Doutrinariamente, tornou-se necessário estender o elemento material do serviço público para que ele pudesse compreender também a prática de atividades comerciais e industriais pelo Estado Moderno, justificando daí a classificação dos serviços públicos em (i) inerentes e (ii) por opção político-constitucional, objeto de tratamento mais detalhado a seguir.

\section{Serviços públicos: (i) inerentes ou (ii) por opção político-constitucional}

26. Na medida em que se passou a aplicar à categoria de serviço público os mais variados conteúdos, esse elemento substancial ou material restou desacreditado como critério capaz de conceituá-lo. Nessa linha, Celso Antônio Bandeira de Mello cuidou de registrar a insuficiência do elemento material para configurar a noção jurídica de serviço público, na passagem que se transcreve:

"Percebe-se, sem muita dificuldade, então, que o primeiro elemento do serviço público é absolutamente insuficiente para configurá-lo, de vez que se trata de simples suporte fático, substrato material, sobre que se constrói a noção jurídica propriamente dita. Por isso, tal substrato pode existir inúmeras vezes sem que, entretanto, se possa falar em serviço público. Isto é, quando houver prestação de utilidade ou comodidade, oferecida pelo Estado e fruivel diretamente pelos administrados, haverá serviço governamenáal, mas nāo necessariamente serviço público. Este só existirá se o regime de sua prestação for o regime administrativo, ou seja, se a prestação em causa configurar atividade administrativa pública, eln una palavra, atividade prestada sob o regime de Direito Público. "26

27. Tanto assim que a doutrina preocupou-se em formular classificações teóricas para dar conta dessa circunstância de ampliação da noção de serviços públicos ${ }^{27}$, observando que, embora se possa assinalar a existência de serviços ontologicamente públicos - isto é, que se relacionam intimamente, em dado momento histórico, com as atribuiçōes advindas da própria soberania estatal -, outros só são assim considerados por mera opção política. A propósito, confira-se a lição de Hely Lopes Meirelles:

26 Celso Antônio Bandeira de Mello, Curso de direito administrativo, 1997, p. 426-7.

27 René Chapus, Droit Administratif General, 9" ed., 1995, p. 526: “Les rapports d'un service administratif avec ses usagers, son personnel et les tiers sont em principe régis par le droit public, alors que c'est le droit privé qui s'applique en principe aux relations d'un service public industriel et commercial avec ses usagers (volontiers qualifiés de 'clients'), son personnel et les tiers.". 
"Também não é a atividade em si que tipifica o serviço público, visto que algumas tanto podem ser exercidas pelo Estado quanto pelos cidadãos, como objeto da iniciativa privada, independentemente de delegação estatal, a exemplo do ensino, que, ao lado do oficial, existe o particular, sendo aquele um serviço público e este, não. O que prevalece é a vontade soberana do Estado, qualificando o serviço como público ou de utilidade pública, para sua prestação direta ou indireta, pois serviços há que, por natureza, são privativos do Poder Público e só por seus órgãos devem ser executados, e outros são comuns ao Estado e aos particulares. podendo ser realizados por aqueles e estes. Dai a gama infindável de serviços que ora estão exclusivamente com o Estado, ora com o Estado e particulares e ora unicamente com particulares. Essa distribuição de serviços não é arbitrária, pois atende a critérios jurídicos, técnicos e econômicos, que respondem pela legitimidade, eficiência e economicidade na sua prestação." 28

28. Neste último caso, isto é, quando a atividade desenvolvida não se relaciona de forma inerente com o poder de império do Estado, a doutrina acaba por resignar-se em encontrar no elemento normativo a definição, afinal, do conceito. Assim, nessas hipóteses, será serviço público a atividade que a norma definir como tal, submetendo-a a uma disciplina jurídica específica. À vista desta constatação, registra Miguel Reale, não sem certo desalento: "no fundo, serviço público é aquele que, em cada conjuntura, a lei configura como tal, razão pela qual só subsistem, a respeito, definiçōes genéricas." "\#̈

29. Nada obstante, e como se vê, a distinção com base no critério material não deixou de ser importante. Ao contrário, é exatamente com base nele que se pode identificar, de um lado, os serviços públicos inerentes e, de outro, os serviços públicos que apenas o são por uma escolha política veiculada em lei ou na própria Constituição. O tema merece um pouco mais de atenção, pois não se trata de classificação puramente doutrinária ou acadêmica. Ao contrário, pertencer a uma dessas duas classes acarreta importantes consequiências do ponto de vista jurídico.

30. Como já referido, os serviços públicos inerentes são aqueles genética ou ontologicamente ligados às funções estatais típicas, que decorrem de seu poder de império, pois envolvem alguma dose de autoridade pública, sendo mesmo difícil imaginar que pudessem ser prestados por particulares. Em sendo assim, e essa a primeira consequiência da distinção, não há necessidade de qualquer previsão de direito objetivo definindo tais atividades como serviços públicos, pois isso decorre implicitamente de sua própria natureza.

31. É despicienda. portanto, qualquer norma que declare, por exemplo, que a prestação jurisdicional com emprego de coação ou a defesa nacional são serviços públicos, na medida em que o exercício dessas funções não pode ser dissociado da própria razão de ser do Estado. A estas atividades a doutrina costuma também chamar

28 Hely Lopes Meirelles, Direito Administrativo brasileiro. 1993, p. 295.

29 Miguel Reale, Temas de direito positivo, 1992, p. 136. 
de serviços públicos propriamente ditos ou serviços próprios do Estado. Confíra-se mais uma vez a conceituação de Hely Lopes Meirelles:

"Serviços Públicos propriamente ditos, são os que a Administração presta diretamente à comunidade, por reconhecer sua essencialidade e necessidade para a sobrevivência do grupo social e do próprio Estado. Por isso mesmo, tais serviços são considerados privativos do Poder Público, no sentido de que só a Administração deve prestá-los, sem delegação a terceiros, mesmo porque geralmente exigem atos de império e medidas compulsórias em relaçāo aos administrados. Exemplos desses serviços são os de defesa nacional, os de policia, os de preservação da saúde pública. (...)

Serviços próprios de Estado são aqueles que se relacionam intimamente com as atribuições do poder Público (segurança, polícia, higiene e saúde pública etc.) e para a execução dos quais a administração usa de sua supremacia sobre os administrados. Por esta razão, só devem ser prestados por órgãos ou entidades públicas, sem delegação a particulares. Tais serviços, por sua essencialidade, geralmente são gratuitos ou de baixa remuneração, para que fiquem ao alcance de todos os membros da coletividade." 30

32. Ao lado dos serviços públicos inerentes, há aquelas atividades que, embora tenham conteúdo tipicamente econômico, e não de serviço público, assim foram consideradas por uma norma jurídica. Sua existência decorre não da natureza da atividade mas de uma manifestação de vontade específica do Estado no sentido de que tal atividade, tendo em vista sua relevância ou outras ponderações relacionadas com o interesse público, passe a ser de sua incumbência, avocando, portanto, sua prestação e gestão ${ }^{31}$. A diferença entre o serviço público inerente e o que decorre de uma opção político-normativa é, como se vê, fundamental.

33. Ora bem. Se o serviço público inerente dispensa previsão legal e decorre da própria existência do Estado, não se trata, como intuitivo, de esfera de atuação privada, mas tipicamente pública. O serviço público que decorre de uma opção política, ao contrário - e aqui se está cuidando do serviço público em sua forma tradicional - , depende de previsão normativa que exatamente opera a retirada de

30 Hely Lopes Meirelles, Direito Administrativo brasileiro, 1993, p. 295.

31 É interessante notar que o espectro dessas tarefas invocadas pelo Estado teve grande variação ao longo do tempo. Sob esse prisma, podem ser observadas três fases bem nítidas, desde o início deste século: a pré-modernidade, em que o Estado possuía funções reduzidas, confinadas à segurança. justiça e serviços essenciais, a modernidade, época em que o Estado assume diretamente diversos papéis econômicos e a pós-modernidade, onde prepondera o discurso da flexibilização, privatização e maior atuação das organizações não-governamentais. Sobre o tema, v. Luís Roberto Barroso, Intervenção no domínio econômico. Sociedade de economia mista. Abuso de poder econômico. Revista de Direito Administrativo $n^{\circ} 212$, p. 303 e ss. e Norbert Reich, Intervenção do Estado na economia (reflexōes sobre a pós-modernidade na teoria jurídica), Revista de Direito Público n 94, p.265 e ss.. 
uma determinada atividade do domínio da livre iniciativa transferindo-a para o controle estatal. $O$ particular não poderá mais desenvolver livremente aquela atividade, como decorreria da aplicação do princípio da livre iniciativa; ela passou a ser titularizada pelo Poder Público, que a exercerá diretamente ou delegará sua exploração aos particulares, mediante concessão ou permissão, mas sempre sob o controle estatal. Essa é, portanto, a característica do serviço público por opção político-normativa tradicional, cuja delegação ao particular se dá na forma do art. 175 da Constituição Federal ${ }^{32}$. Não é difícil perceber que o serviço público por opção política representa, na verdade, uma drástica restrição ao princípio constitucional da livre iniciativa.

34. Já se pode, neste ponto, chegar a uma conclusão. Se a criação de serviços públicos não inerentes, por mera opção política, diminui o campo de incidência da livre iniciativa - o que de fato ocorre ${ }^{33}$ - ela só será possível com fundamento em autorização ou previsão constante da Lei Maior. Caso contrário, estar-se-ia admitindo que uma norma infraconstitucional, de inferior hierarquia, violasse uma norma constitucional - a que consagra a livre iniciativa e todas as demais que a complementam ou lhe servem de pressuposto ${ }^{34}$. Ademais, tal criação há de ser sempre balizada pelo critério da razoabilidade, a fim de evitar abusos que busquem esvaziar indiretamente a livre iniciativa.

35. Não por outra razão a Constituição de 1988 cuidou, ela própria e analiticamente, dessa categoria de serviços públicos. Além de enumerar as atividades que decidiu seriam serviços públicos, nada obstante sua natureza tipicamente econômica, dispôs acerca da possibilidade genérica de delegação de sua execução a particulares, mediante concessão ou permissão (art. 175), e os repartiu entre os entes federativos (arts. 21, XI e XII, 25, § $2^{\circ}$, e 30, V).

32 Carlos Ari Sundfeld, Loterias estaduais na Constituiçâo de 1988, Revista de Direito Público $n^{\circ}$ 91, p. 97: "De outro lado, existem os serviços públicos, titularizados pelo Estado, que deve realizá-los diretamente ou através de particulares concessionários ou permissionários (art. 175 , caput). Os serviços públicos são, destarte, atividades exclusivas do Estado, monopolizadas por ele. e só podem ser prestadas por terceiros quando investidos de uma delegação estatal".

33 Gaspar Ariño Ortiz. Servicio público y libertades públicas, in Expansión, 1999, apud Fábio Medina Osório, Direito administrativo sancionador 2000, p. 42. Para o autor espanhol: "donde aprece en las Leyes el concepto de servicio público desaparecen, antes o después, las libertades públicas. Servicio público y libertades públicas son (en gran medida) incompatibies." E explica: "La razón es sencilla: el servicio público, por definición, supone la assunción por el Estado - la publificación - de un conjunto de actividades de la vida social que, a partir del momento de su declaración legal, pasan a incorporarse al ámbito de actuación del Estado, esto es, se convierten en tarea estatal, quaedando vetadas en lo sucesivo a la libre iniciativa empresarial.".

34 Toda interpretação constitucional se assenta na premissa da superioridade jurídica da Constituição sobre os demais atos normativos no âmbito do Estado. Conforme a teoria clássica, a Constituição é documento dotado de supremacia no ordenamento jurídico estatal, servindo de fundamento de validade a todos os demais atos normativos que lhe são inferiores. A supremacia da Constituição subordina o conteúdo de toda a atividade normativa estatal à conformidade com os princípios e regras da Lei Maior. Veja-se, a respeito do tema: Hans Kelsen, Teoria pura do direito, 1979, p. 310 e J.J. Gomes Canotilho, Direito constitucional, 1991, p. 141-2. 
36. Veja-se que a Constituição, atenta ao caráter excepcional de tais serviços públicos por definição normativa, identifica-os de maneira expressa. De fato, ao enunciar os serviços públicos dessa natureza que caberiam à União, aos Estados e aos Municípios - arts. 21, XI e XII, 25, § $2^{\circ}$, e 30, V ${ }^{35}$ - teve o cuidado de utilizar a expressão "explorar o serviço x diretamente ou mediante concessão ou permissão", ou outra similar. Preocupou-se em deixar claro que tais atividades só poderiam ser desempenhadas pelos particulares mediante delegação do Poder Público, por terem sido subtraídas da livre iniciativa. Nada disso acontece, v.g., quando a Constituição afirma competir à União "assegurar a defesa nacional" ou "emitir moeda" (art. 21, III e VII), que são inequivocamente serviços públicos inerentes.

37. Vale fazer o registro que, nessa linha, parte da doutrina entende mesmo que a lei não pode criar novas modalidades de serviços públicos por opção normativa, além dos que já constam da Constituição Federal. Do contrário, argumenta-se, a atribuição do status de serviço público a toda e qualquer atividade que aprouvesse ao legislador ordinário, retirando-as da livre iniciativa do particular, estaria em franca oposição ao princípio fundamental da livre iniciativa. A lei ordinária, portanto, não poderia ampliar as hipóteses de intervenção estatal na ordem econômica através da prestação de serviços públicos, sob pena de tornar inócua a previsão do art. $1^{\circ}$, inciso IV, da $\mathrm{CF}^{36}$.

38. No caso da União Federal, a esse argumento se agregaria outro, que diz respeito à técnica de repartição de competências adotada pelo constituinte originário. Com efeito, a Constituição de 1988 manteve a técnica de repartição de competências

35 “Art. 21. Compete à União: (...) XI - explorar, diretamente ou mediante autorização, concessão ou permissão, us serviços de telecomunicações, nos termos da lei, que disporá sobre a organização dos serviços, a criação de um órgão regulador e outros aspectos institucionais; XII - explorar, diretamente ou mediante autorização, concessão ou permissão: a) os serviços de radiodifusão sonora e de sons e imagens; b) os serviços e instalações de energia elétrica e o aproveitamento energético dos cursos de água, em articulação com os Estados onde se situam os potenciais hidroenergéticos; c) a navegação aérea, aeroespacial e a infra-estrutura aeroportuária; d) os serviços de transporte ferroviário e aquaviário entre portos brasileiros e fronteiras nacionais, ou que transponham os limites de Estado ou Território; e) os serviços de transporte rodoviário interestadual e internacional de passageiros; f) os portos marítimos, fluviais e lacustres."

“Art. 25. (...) $\S 2^{\circ}$ Cabe aos Estados explorar diretamente, ou mediante concessão, os serviços locais de gás canalizado. na forma da lei, vedada a edição de medida provisória para a sua regulamentação."

"Art. 30. Compete aos Municípios: (...) V - organizar e prestar, diretamente ou sob regime de concessão ou permissão, os serviços públicos de interesse local, incluído o de transporte coletivo, que tem caráter essencial."

36 Fernando Herren Aguiliar. Controle social de serviços públicos, 1999, p. 133: "O regime de privilégio típico dos serviços públicos (...) opera verdadeiro monopólio de uma dada atividade econômica. Daí que o mesmo regime imposto ao Estado para o fim de monopolizar uma determinada atividade econômica é também aplicável para as hipóteses de criação de novo serviço público. (...) Assim, se não quisermos desconsiderar o art. 173, teremos que admitir, logicamente, que somente é possível instituir Serviços Públicos não previstos constitucionalmente mediante emenda constitucional. (...) os serviços públicos no regime constitucional vigente não podem ser instituídos por lei, inovadoramente em relação à lista de serviços públicos constitucionais." 
entre os entes federativos, de inspiração norte-americana e adotada no Brasil desde 1891, pela qual reservam-se à União Federal e aos Municípios competências expressas $^{37}$, deixando a cargo dos Estados-membros as chamadas competências residuais ou remanescentes (art. $\left.25, \$ 2^{\circ}\right)^{38}$. Além dessas competências exclusivas - que desempenham sem a participação de qualquer outro - a Constituição prevê ainda competências concorrentes, em áreas que comportam a atuação das diferentes esferas de poder da federação.

39. Nesse contexto, a União não poderia criar, através de lei, novos serviços públicos não inerentes - isto é, transformar, por lei, atividades econômicas em serviços públicos em conseqüência de uma opção política - , além dos constitucionalmente previstos, sob pena de violação da competência remanescente dos Estados membros (art. $25, \S 1^{\circ}$, da $\mathrm{CF}$ ). A esse propósito, Celso Ribeiro Bastos assinalou:

"A nossa Constituição reserva para si esta tarefa de definir quais são os serviços públicos. Reparte-os entre a União, os Estados e os Municípios, segundo um rol de competências que ela mesma estipula. Para a União, temos o art. 21, $X I I$, que deixa certo pertencer a ela para ser explorado diretamente ou mediante autorização, concessão ou pernissão tudo o que vem arrolado nas cinco letras daquele inciso. Quanto aos Estados há pelo menos uma referência a um serviço público de sua alçada, previsto no art. $25, \S 2^{\circ}$, que se refere aos serviços locais de gás canalizado. Aos Municípios compete organizar e prestar os serviços públicos de interesse local, incluído o transporte coletivo." 39

40. Independentemente de aceitar-se ou não a tese da total impossibilidade de criação legislativa de novos serviços públicos por opção normativa, o fato é que essa modalidade de serviço público constitui, sem qualquer dúvida, restrição ao princípio da livre iniciativa. Sendo assim, só será admitida com fundamento, ainda que genérico, em outra norma constitucional e, em qualquer caso, deverá ser interpretada restritivamente, como convém a normas excepcionais e restritivas de direitos ${ }^{40}$.

37 No caso dos Municípios, as competências são, mais precisamente, referenciadas à noção de interesse local.

38 “Art. 25 (...)

$\S 1^{\circ}$ São reservadas aos Estados as competências que não lhes sejam vedadas por esta Constituição."

39 Carlos Ari Sundfeld, Sistema Constitucional de Competências, Revista Trimestral de Direito Público $\mathrm{n}^{\circ}$ 1, p. 272.

40 Carlos Maximiliano. Hermenêutica e Aplicação do Direito, 1980, pp. 227: “As disposições excepcionais são estabelecidas por motivos ou considerações particulares, contra outras normas jurídicas, ou contra o Direito comum; por isso não se estendem além dos casos e tempos que designam expressamente."

No mesmo sentido a jurisprudência do Supremo Tribunal Federal: “(...) A exceção prevista no parágrafo $5^{\circ}$ do artigo 29 do ADCT ao disposto no inciso IX do artigo 129 da parte permanente da Constituição Federal diz respeito apenas ao exercício da advocacia nos casos ali especificados, e, por ser norma de direito excepcional só admite interpretação estrita, não sendo aplicável por 
41. No que diz respeito às normas constitucionais que tratam do assunto, é importante reiterar, consolidando o que já se expôs, que a Carta adotou dupla cautela: (i) enumerou as hipóteses de serviços públicos por opção normativa, referindo de forma expressa que o acesso dos particulares a elas só poderia se dar através de concessão ou permissão; como também (ii) adotou dispositivos com redação específica, deixando claro tratarem-se de atividades econômicas que, por variadas razões, foram retiradas da esfera dos particulares.

42. Vale referir, como nota final deste tópico, que é possível identificar, ao lado desses serviços públicos que se acaba de descrever, uma outra categoria, ainda no âmbito dos serviços públicos por opção político-normativa, considerando-se a forma como os particulares podem vir a ter acesso a tais atividades.

43.A regra aplicável aos serviços públicos em geral, não há dúvida, é dada pelo art. 175 da Constituição. Todavia, o próprio constituinte cuidou de excepcionar a aplicação desse dispositivo a alguns serviços que, nada obstante serem prestados pelo Estado, foram franqueados diretamente aos particulares pela própria Constituição. A exploração desses serviços pela iniciativa privada, diferentemente da regra geral, dependerá apenas, se for o caso, de licença prévia da autoridade competente - ato administrativo vinculado - , uma vez atendidas as exigências legais ${ }^{4 !}$.

44.Enquadram-se nessa categoria, especificamente, os serviços de educação (art. 209), saúde (art. 199) e previdência (art. 201 e seguintes). Estes os dispositivos constitucionais pertinentes, in verbis:

"Art. 209. O ensino é livre à iniciativa privada, atendidas as seguintes condições:

(...)

II - autorização e avaliação de qualidade pelo Poder Público."

"Art. 199. A assistência à saúde é livre à iniciativa privada."

"Art. 202. O regime de previdência privada, de caráter complementar e organizado de forma autônoma em relação ao regime geral de previdência social, será faculıativo, baseado na constituição de reservas que garantam o benefício contratado, e regulado por lei complementar."

analogia, e portanto. não indo além dos casos nela expressos, nem se estendendo para abarcar as consequiências lógicas desses mesmos casos, (...)." (STF, ADIn 41/DF, Relator Ministro Moreira Alves, DJ 28/06/91).

41 Hely Lopes Meirelles, Direito administrativo brasileiro, 1993, p.: 170: "Licença é o ato administrativo vinculado e definitivo pelo qual o Poder Público, verificando que o interessado atendeu a todas as exigências legais, faculta-lhe o desempenho de atividades (...)". A Lei de Diretrizes e bases (Lei $n^{\circ} 9.394$, de 20/12/96), estabelece as normas a que as instituições de ensino privadas estão submetidas. A Lei $n^{\circ} 6.435$, de $20 / 07 / 77$, dispõe sobre a necessidade de "prévia autorização" do Governo Federal para o funcionamento de entidades de previdência privada, embora o termo técnico devesse ser licença, e não autorização. A Lei n 8.080, de 19/09/90, da mesma forma, cuida das normas aplicáveis aos serviços privados de assistência à saúde. 
45. A peculiaridade desses servıços está, portanto, em que a atuação do Estado não impede que os particulares explorem a mesma atividade concomitantemente, afastando, por expressa previsão da própria Carta, a incidência do art. 175. A razão de tal regime jurídico é o interesse público em que a oferta de tais serviços seja a maior possível, observados apenas os requisitos mínimos legais.

46. Seria possível, mesmo, especular que o serviço postal estaria enquadrado nessa categoria: assegurada a prestação mínima pelo Estado, poderia a iniciativa privada multiplicar a oferta, propiciando benefícios aos usuários relativamente à qualidade e ao preço. Por essa linha de entendimento, qualquer empresa estaria habilitada a atuar no setor, observada a legislação própria, desde que existente.

47. Estou convencido, no entanto, que o chamado "serviço postal" não é serviço público, mas atividade econômica. Nas páginas seguintes procura-se demonstrar o argumento.

\section{b) Desempenho de atividade econômica}

48. O mesmo contexto histórico que acarretou a ampliação, acima referida, do conteúdo material da noção de serviço público explica também o novo papel do Estado no desempenho de atividades econômicas nessa qualidade. Com efeito, ao longo deste século, em determinados momentos (de crise, e.g.) e lugares (países em desenvolvimento, e.g.), entendeu-se que o Estado deveria assumir o papel de empresário, como se fosse um particular, e empenhar-se na exploração e desenvolvimento de determinada atividade econômica.

49. As razões que explicam essa atuação estatal atípica eram as mais diversas: desde a necessidade urgente de geração de empregos em um momento de crise grave, como em 1929, nos EUA, até a incapacidade de investimentos do setor privado, hipótese recorrente nas décadas de 40 e 50 nos países em desenvolvimento ${ }^{42}$. De toda sorte, ainda que este seja um movimento em claro refluxo neste fim de século, a exploração direta pelo Estado de atividade econômica foi uma fórmula para atender determinados interesses públicos sem acarretar, necessariamente, o inconveniente de bloquear o acesso do particular a essas atividades. De fato, isto é o que aconteceria se se optasse por uma caracterização como serviço público por opção político-normativa, em sua forma tradicional, que, como regra, interdita a atuação privada, salvo mediante delegação.

50. Note-se que, do ponto de vista operacional, o regime dos serviços públicos que a Constituição delegou de forma direta aos particulares - educação, saúde e previdência privada, acima referidos - aproxima-se do adotado para a exploração direta pelo Estado de atividade econômica, já que não afasta a possibilidade de exploração concomitante pelos particulares, independentemente de concessão ou permissão. Há inclusive quem defenda que educação, saúde e previdência consti-

42 Sobre o tema, veja-se: Luís Roberto Barroso, Crise econômica e direito constitucional, Revista Trimestral de Direito Público n 6, p. 32 e ss.. 
tuem, em verdade, atividades econômicas, e não serviços públicos ${ }^{43}$. A discussão doutrinária é instigante, porém indiferente para a questão suscitada pelo consulente.

51. Feita a digressão, e retornando ao desenvolvimento que se vinha dando ao tema, o fato é que a possibilidade de acesso direto do particular às atividades em questão é, portanto, o diferencial mais relevante que distingue o serviço público por opção normativa tradicional do desempenho pelo Estado de determinada atividade econômica. Embora ambas as modalidades de intervenção na seara econômica possam acabar versando sobre a mesma atividade concreta ${ }^{44}$, a atuação do Estado como agente econômico, nas mesmas condições que os particulares, afeta em menor intensidade o princípio da livre iniciativa, na medida em que não os proíbe de desenvolverem também a atividade. A questão, entretanto, ainda abriga mais uma complexidade, pois a Constituição prevê hipóteses em que o Estado não estará atuando nas mesmas condições que os particulares.

52. De fato, do exame sistemático da Constituição Federal de 1988 é possível classificar o desempenho pelo Estado de atividade econômica em duas categorias. A primeira, e a mais importante para os fins deste estudo, diz respeito à forma de atuação estatal. A Constituição prevê 2 (dois) regimes: (i) sob forma monopolizada; e (ii) sob forma não monopolizada e regime concorrencial A segunda dessas categorias descreve a intervenção do Estado no que diz respeito à sua necessidade do ponto de vista constitucional. Sob este ângulo, as atividades podem ser classificadas em (i) obrigatórias, por previsão constitucional específica, e (ii) facultativas, por opção legislativa. Explica-se a seguir cada uma dessas classificações.

Formas de atuação estatal no desempenho de atividade econômica: (i) monopolizada e (ii) não monopolizada e sob regime concorrencial.

53. A forma padrão de atuação do Estado como agente econômico é a não monopolizada sob regime concorrencial, pela qual ele atua como empresário mas sem impedir o acesso dos particulares à atividade em questão, e em condições de

43 Fernando Herren Aguillar, Controle social de serviços públicos, 1999, p. 139: "Tais conclusōes nos parecem logicamente inafastáveis em decorrência da leitura do art. 175. Elas nos permitem refutar categoricamente, por exemplo, a tradicional classificação doutrinária segunda a qual os serviços de saúde e educação seriam serviços públicos quando desempenhados pelo Estado, mas não o seriam quando fossem desempenhados pela iniciativa privada. Essa conclusão é logicamente inaceitável, visto que, se os particulares podem desempenhar essas atividades sem concessão ou permissão, então, seguindo-se as premissas ' $b$ ' e 'e' acima, não podem ser consideradas como serviços públicos. Saúde e educação são, pois, funções irrenunciáveis do Estado, como veremos adiante, mas que na atual sistemática constitucional podem ser desempenhadas livremente pela iniciativa privada. Não são serviços públicos em sentido estrito, mas funções do Estado."

44 Eros Roberto Grau, A ordem econômica na Constituição de 1988, 1998, p. 132: "Insista-se em que atividade econômica em sentido amplo é território dividido em dois campos: o do serviço público e o da atividade econômica em sentido estrito. As hipóteses indicadas no art. 173 do texto constitucional são aquelas nas quais é permitida a atuação da União, dos Estados-membros e dos Municípios neste segundo campo." 
igualdade com a iniciativa privada. Isto é: a atuação estatal exige que sejam asseguradas condições de competitividade equivalentes, para que não venha a sufocar os atores privados, beneficiando-se de condições privilegiadas. Isso é o que prevê de forma expressa o art. 173 da Constituição, in verbis:

“Art. 173. Ressalvados os casos previstos nesta Constituição, a exploração direta de atividade econômica pelo Estado só será permitida quando necessária aos imperativos da segurança nacional ou a relevante interesse coletivo, conforme definidos em lei."

54. É importante notar que, embora seja a forma menos gravosa à livre iniciativa, também esta modalidade de exercício de atividade econômica é considerada excepcional, como consta expressamente do artigo transcrito, só se admitindo sua criação por lei no caso de imperativos da segurança nacional ou relevante interesse coletivo.

55. Os parágrafos e incisos do artigo 173 estabelecem as normas gerais a serem observadas no desenvolvimento dessas atividades. Em primeiro lugar, o Estado deve instituir uma das duas formas empresariais previstas no dispositivo: empresa pública ou sociedade de economia mista. Essas empresas paraestatais, por sua vez, deverão submeter-se ao regime próprio da iniciativa privada, inclusive quanto às obrigações civis, comerciais, trabalhistas e tributárias, como deixa claro o $\S 1^{\circ}$, II. e $\S 2^{\circ}$ do art. 173, da Carta, de modo a evitar a concorrência desleal em relação aos competidores privados. Vale conferir o teor do dispositivo, in verbis:

“Art. 173 (...)

$\$ 1^{\circ}$ - A lei estabelecerá o estatuto jurídico da empresa pública. da sociedade de economia mista e de suas subsidiárias que explorem atividade econômica de produção ou comercialização de bens ou de prestação de serviços, dispondo sobre:

(...)

II - a sujeição ao regime jurídico próprio das empresas privadas, inclusive quanto aos direitos e obrigações civis, comerciais, trabalhistas e tributários; (...)

$\S 2^{\circ}$ - As empresas públicas e as sociedades de economia mista não poderão gozar de privilégios fiscais não extensivos às do setor privado."

56. É evidente que tais empresas, integrantes que são da administração pública indireta, estāo obrigadas a observar os princípios e regras de direito público expostos no art. 37 e seguintes da Constituição. O essencial, no entanto, é que a Carta de 1988 procura assegurar que o Estado-empresário atue em condições de igualdade em relação aos particulares, seus competidores, a fim de evitar a concorrência desleal ${ }^{45}$.

45 Diogo de Figueiredo Moreira Neto, Curso de direito administrativo, 1997, p. 369: “Mesmo atuando concorrentemente, o Estado empresário, através de suas empresas públicas, sociedades de economia mista ou de outros tipos de entidades, sujeitar-se-á ao regime jurídico próprio das 
57. A outra forma de atuação do Estado para o exercício de atividade econômica é a monopolizada, situação absolutamente excepcional, que a Constituição sequer admite seja reproduzida pelo legislador ordinário. Tal forma de atuação só convive com o princípio da livre iniciativa, com o qual se confronta, por força do princípio da unidade, pelo qual todas as normas constitucionais originárias têm a mesma hierarquia e harmonizam-se, por meio de uma interpretação sistemática, de modo a garantir a integridade do texto $0^{46}$.

58. A Carta de 1988, nada obstante substanciais alterações empreendidas nos últimos anos por meio de várias emendas constitucionais, ainda prevê a reserva de atividades econômicas à exploração direta e monopolizada da União. É o caso, v.g., dos ciclos econômicos dos minérios e minerais nucleares e do petróleo (art. 177, I a $\mathrm{V}, \mathrm{da} \mathrm{CF})^{47}$. Ora, como se sabe, atividade monopolizada é aquela cuja mercadoria ou serviço só são fornecidos por uma única empresa, que tem, portanto, a prerrogativa de fixar-lhe o preço ${ }^{48}$. No caso, o exercício de atividade econômica pelo Estado em regime de monopólio significa que tais atividades não apenas passam a ser exercidas pelo Estado, como que os particulares estão impedidos de explorá-las.

59. É o que basta para a verificação de que o monopólio é a antítese, a negação, da livre iniciativa. Por esse motivo, a doutrina é pacífica em afirmar que, a partir da entrada em vigor da nova Carta, só são admitidos os monopólios estatais por ela previstos expressamente; lei alguma pode criá-los. Lembre-se, aliás, que a Constituição de 67/69 admitia que a lei, respeitados determinados requisitos, pudesse instituir monopólios ${ }^{49}$. Não mais assim na nova Constituição, que deixou de repro-

empresas privadas. inclusive quanto às obrigações trabalhistas e tributárias, não podendo gozar de quaisquer privilégios fiscais que não sejam extensivos ao setor privado (art. $173, \S \S 1^{\circ}$ e $2^{\circ}, \mathrm{CF}$ ). Garante-se, destarte. que a ineficiência do Estado empresário não se mascare por trás de privilégios que, em última análise, oneram o público, como consumidor, como usuário e como contribuinte, assegurando-se. sobretudo, o primado da livre concorrência."

Esse também o entendimento do STF, in verbis: "O artigo $173, \S 1^{\circ},(\ldots)$ visa a assegurar a livre concorrência. de modo que as entidades públicas que exercem ou venham a exercer atividade econômica nāo se beneficiem de tratamento privilegiado em relação a entidades privadas que se dediquem a atividade econômica na mesma área ou em área semelhante." (STF, RE $n^{\circ} 172.816$, Relator Ministro Paulo Brossard, DJ 09/02/94).

46 A propósito, já averbamos em outro trabalho: "O papel do princípio da unidade é o de reconhecer as contradiçōes e tensōes - reais ou imaginárias - que existam entre normas constitucionais e delimitar a força vinculante e o alcance de cada uma delas. Cabe-lhe, portanto. o papel de harmonização ou "otimização" das normas, na medida em que se tem de produzir um equilíbrio, sem jamais negar por completo a eficácia de qualquer delas." (Luís Roberto Barroso, Interpretação e aplicação da Constituição, 3* ed., 1999, p. 185).

47 O monopólio das atividades relacionadas a minérios e minerais nucleares é absoluto, mas no que diz respeito às que envolvem petróleo, a União, embora detendo o monopólio, poderá contratar empresas estatais ou privadas (art. $177, \S 1^{\circ}$ ).

48 V. Nelson Eizirik. Monopólio estatal da atividade econômica, Revista de Direito Administrativo $n^{\circ} 194$, p. 73.

49 "Art. 163. São facultados a intervenção no domínio econômico e o monopólio de determinada indústria ou atividade. mediante lei federal, quando indispensável por motivo de segurança nacional 
duzir o dispositivo. Essa é a opinião, dentre outros ${ }^{50}$, de Fábio Konder Comparato e Celso Antônio Bandeira de Mello e Nelson Eizirik, respectivamente:

"A vigente Carta Constitucional preferiu seguir o critério de enumeração taxativa dos setores ou atividades em que existe (independentemente, pois, de criação por lei) monopólio estatal, deferido agora exclusivamente à Uniäo (art. 177 e $21, X, X I$ e XII). Quer isto dizer que, no regime da Constituição de 1988, a lei já não pode criar outros inonopólios, não previstos expressamente no texto constitucional, pois contra isso opõe-se o princípio da livre iniciativa, sobre o qual se funda toda a ordem econômica (art. 170)."\$1

"Finalmente, convém lembrar que a Constituição previu o monopólio de certas atividades. São elas unicamente as seguintes, consoante arrolamento do art. 177 da Constituição (...) Tais atividades monopolizadas não se confundem com serviços públicos. Constituem-se, também elas, em 'serviços governamentais', sujeitos, pois, às regras do Direito Privado. Correspondem, pura e simplesmente, a atividades econômicas subtraídas do âmbito da livre iniciativa." ${ }^{52}$

"Com relação à intervenção monopolista do Estado na atividade econômica, embora tenha a vigente Constituição ampliado o elenco de hipóteses em que ela ocorre, impossibilitou-se a criação de novos monopólios estatais, salvo por emenda constitucional." 53

Necessidade de atuação estatal no desempenho de atividade econômica: (i) atividades obrigatórias por disposição constitucional expressa; e (ii) atividades facultativas, por opção legislativa.

60. Além da forma como o Estado pode desempenhar atividades econômicas, sua atuação nesse âmbito também pode ser classificada em função da imperatividade ou não da intervenção. De fato, há atividades econômicas que a Constituição expressamente determina que o Estado desenvolva. E há, por outro lado, o art. $173 \mathrm{da}$ Carta, que veicula cláusula geral permitindo que a lei, atendidos os pressupostos constitucionais (imperativos da segurança nacional ou a relevante interesse coleti-

ou para organizar setor que não possa ser desenvolvido com eficácia no regime de competição e de liberdade de iniciativa, assegurados os direitos e garantias individuais."

50 V. Pinto Ferreira, Comentários à Constituição brasileira, 1994, p. 386 e J. Cretella Jr., Comentários à Constituição de 1988, vol. VIII. 1998, p. 4.152 e ss..

51 Fábio Konder Comparato, Monopólio público e domínio público in Direito Público: estudos e pareceres, 1996, p. 149.

52 Celso Antônio Bandeira de Mello, Curso de direito administrativo, 1996, p. 441.

53 Nelson Eizirik, Monopólio estatal da atividade económica, Revista de Direito Administrativo $n^{\circ} 194$, p. 63. 
vo), decida a respeito da exploração de determinada atividade econômica pelo Poder Público. Estas, portanto, hão de ser atividades facultativamente empreendidas pelo Estado, de acordo com a avaliação do legislador ordinário.

61. As atividades determinadas pela Constituição como de prestação obrigatória correspondem a decisões políticas do próprio constituinte originário a respeito daqueles pressupostos - imperativos da segurança nacional e relevante interesse coletivo. Podem ser incluídos nesta categoria, v.g., o serviço de estatística, geografia, geologia, cartografia (art. 21, XV) e o serviço postal e o correio aéreo nacional (art. $21, X)^{54}$.

\section{NATUREZA CONSTITUCIONAL DO SERVIÇO POSTAL}

62. Na primeira parte deste trabalho procurou-se estabelecer de forma ordenada, conquanto inevitavelmente analítica, o sistema constitucional da intervenção do Estado na ordem econômica. Firmados os pressupostos teóricos, investiga-se, agora, a natureza do serviço postal e da atuação da Empresa Brasileira de Correios e Telégrafos-EBCT, bem como a possibilidade de exploração por particulares do serviço postal.

\section{II.1. O serviço postal não é serviço público}

$63 . \mathrm{O}$ art. 21, X, da Constituição de 1988 dispõe que "Compete à União manter o serviço postal e o correio aéreo nacional". A primeira questão a saber, portanto, é se essa atuação do Estado na ordem econômica assume a forma de um serviço público - inerente ou por opção político-normativa - ou se se trata do desempenho de uma atividade econômica. A conclusão, como se verá, é que o Estado, ao explorar o serviço postal, encontra-se desempenhando uma atividade econômica, e não um serviço público, por uma variedade de motivos.

64.O serviço público, já se expôs, pode ser inerente, isto é, estar intimamente associado às funções estatais e a seu poder de império, ou decorrer de uma opção político-normativa. $\mathrm{O}$ serviço postal e o correio aéreo nacional ${ }^{55}$, todavia, não são serviços públicos inerentes. A demonstração é simples, mas pressupõe breve reflexão sobre a realidade econômica em que se inserem tais atividades, que integram a pré-compreensão do intérprete, sobretudo do intérprete constitucional, que não deve operar com categorias abstratas arbitrárias, mas com dados da realidade e dos problemas concretos que lhe cabe equacionar e resolver ${ }^{56}$.

54 Há autores que. como visto, aqui acrescentam educação (art. 208), saúde (art. 198) e previdência (art. 203).

55 O correio aéreo nacional é espécie do gênero serviço postal, de modo que a referência ao gênero estará automaticamente englobando a espécie.

56 Sobre o tema, v. Konrad Hesse, Elementos de direito constitucional da República Federal da Alemanha, 1998, pp. 61 e ss.. 
65. Houve época em que a infra-estrutura necessária à prestação de serviços postais só poderia ser oferecida pelo Poder Público. As vias de comunicação do país eram precárias. No início da década de 30 , por exemplo, apenas a Aeronáutica tinha condições de fazer o transporte aéreo de correspondência, tanto que o atual Correio Aéreo Nacional (CAN) foi, por bastante tempo, denominado de Correio Aéreo Militar $(\mathrm{CAM})^{57}$, e continua sob operação da FAB. A iniciativa privada não tinha capacidade, nem interesse econômico, em desempenhar essa atividade em todo o território nacional. Em vista disso, atendendo a interesse coletivo, o Estado se incumbiu de tal tarefa, aparelhando-se para a entrega, recebimento e transporte de objetos e correspondências. Desde o século passado, aliás, existia, no âmbito do Poder Executivo, um departamento específico para regular e controlar a prestação de tais serviços, o Departamento dos Correios e Telégrafos - DCT. É razoável crer, nessas circunstâncias, que o serviço postal fosse percebido como um serviço público inerente.

66. A evolução econômica e tecnológica verificada ao longo do século, entretanto, principalmente no âmbito dos meios de comunicação e transporte, mudou esse quadro, conferindo às empresas privadas aptidão para o desempenho eficiente daquelas atividades. Não faz qualquer sentido imaginar hoje, por exemplo, que apenas o Estado possa transportar correspondências por via aérea; muito ao contrário. No mesmo passo, as transformações de ordem social passaram a exigir a prestação de serviços diferenciados e cada vez mais sofisticados, como, v.g., a entrega rápida ou a transferência de recursos por via postal. Já há algum tempo uma demanda mais abrangente por atividades de transporte e entrega de bens criou um mercado que movimenta hoje, só no Brasil, aproximadamente cinco bilhões de reais por ano ${ }^{58}$.

67. A realidade demonstra que, em todo o mundo, a prestação de serviço postal não pressupõe o exercício de um poder estatal: muitos Estados não the atribuem a qualidade de serviço público e outros sequer prevêem essa modalidade de intervenção do Estado na economia ${ }^{59}$. Com efeito, ninguém é capaz de imaginar, na realidade

57 No site oficial do Comando da Aeronáutica (www.aer.mil.br), encontra-se uma significativa passagem sobre o assunto, no texto que conta a história da Aeronáutica brasileira, in verbis: "A 12 de junho de 1931, dois Tenentes da Aviação Militar - Nélson Freire Lavenére-Wanderley e Casimiro Montencgro Filho - pilotando um Curtiss Fledgling, saíram do Rio de Janeiro e chegaram a São Paulo. conduzindo uma mala postal (com 2 cartas). Nascia assim o Correio Aéreo Militar (CAM). Esse CAM, atualmente denominado Correio Aéreo Nacional (CAN), permanece com a missão de assegurar a presença do Governo Federal nos mais diversos rincões do Brasil, o que levou o nosso Congresso, tocado por um forte espírito cívico, a exigir da Força Aérea Brasileira a continuidade da operação do Correio Aéreo Nacional, incluindo-o na Constituição de 1988."

58 Estimativa do Jornal do Brasil, em ampla reportagem intitulada Reforma Postal, publicada na edição de 9 de abril do corrente ano.

59 As cartas constitucionais de alguns estados sequer se referem a serviços postais. Este é o caso, por exemplo. de Portugal, Suécia, Luxemburgo, Itália, Irlanda, Grécia, Dinamarca. França, Finlândia, Bélgica. Bolívia, Colômbia, Costa Rica, Cuba, Chile, Equador. Guatemala. Honduras, Nicarágua e Panamá. Nos Estados Unidos, os serviços postais não são serviços públicos, mas sua Constituição prevê a competência do Congresso em estabelecer agências postais (Article 1. Section 8). Semelhante disposição há na Constituição argentina, que prevê a competência do Congresso 
atual, que o serviço postal só possa ser prestado pelo Estado ou que decorra de alguma de suas funções básicas ${ }^{60}$. O serviço postal, portanto, não é, definitivamente, um serviço público inerente. Resta saber se o direito objetivo brasileiro, por uma opção político-normativa, atribui ao serviço postal tal qualidade. Também aqui a resposta é negativa.

68. A ordem jurídica anterior à Constituição de 1988 não considerava o serviço postal como serviço público - ao menos desde a década de 60 - e também a nova Carta assim não o consagrou. Como já referido, o serviço postal pode ter sido considerado um serviço público no passado, em razão principalmente da falta de capacidade ou interesse da iniciativa privada nesse empreendimento, mas já de algum tempo evoluiu para uma atividade econômica. O marco legal dessa alteração histórica na natureza do serviço postal brasileiro foi a transformação do Departamento de Correios e Telégrafos - DCT, em 1968, em empresa pública, à qual competia, nos termos do Decreto-lei 509, de 20/3/1969, a execução e controle, em regime de monopólio, dos serviços postais. Lembre-se que a Constituição em vigor à época permitia que a lei ordinária instituísse monopólios.

69. Ora bem. Somente atividades econômicas podem ser objeto de monopólio estatal; o Estado o institui exatamente para subtrair da iniciativa privada o exercício de determinada atividade econômica. O serviço público é, por sua própria natureza e definição jurídica, titularizado pelo Estado, de modo que não há necessidade nem lógica em prever, em relação a ele, um regime de monopólio. Os serviços públicos já são, por assim dizer, essencialmente "monopolistas": aos particulares só pode ser delegado seu exercício, e ainda assim mediante um ato negocial específico do Poder Público, precedido de um procedimento administrativo de licitação (art. 175, CF). Consequientemente, basta que não se conceda ou permita a prestação de determinado serviço para que ele seja desempenhado exclusivamente pelo Estado.

70. Essa evidência pode ser observada no próprio texto da Carta de 1988. Todos os casos de monopólio que são ou foram arrolados no texto referem-se a atividades econômicas: exploração de atividades nucleares e petrolíferas (art. 177), e de resseguro (art. 192, alterado pela Emenda Constitucional $n^{\circ} 13$, de 21/8/1996), etc. O mesmo acontecia com a Constituição de 1967/69, cujo art. 163 facultava a "intervenção no domínio econômico e o monopólio de determinada indústria ou atividade, mediante lei federal, quando indispensável por motivo de segurança nacional ou para organizar setor que não possa ser desenvolvido com eficácia no regime de competição e de liberdade de iniciativa." Assim, ao menos desde 1968, o direito

Nacional para estabelecer "las postas y correos generales de la Nación" (art. 67, XIII). Na Alemanha, o serviço postal prestado pelo Estado convive com o privado, explorado como atividade econômica (art. 87). Veja-se, sobre o caso alemão Konrad Hesse, Elementos de direito constitucional da República Federativa da Alemanha, 1998, p. 199/2000.

60 Sobre este ponto, vale o registro de que a exposição de motivos da Proposta de Diretiva $n^{\circ}$ 139/2000, da União Européia, cuidou exatamente de ressaltar a importância econômica dos serviços postais e a necessidade de estimular a concorrência e a competitividade no setor, para garantir sua eficiência. 
brasileiro não considera o serviço postal serviço público, e sim atividade econômica explorada pelo Estado (àquela altura em regime de monopólio).

71. Com o advento da Carta de 1988, o tema ganhou estatura unicamente constitucional, não mais podendo ser alterado pela legislação ordinária ${ }^{6 !}$, mas o sentido manteve-se o mesmo, na tradição do que há décadas já acontecia no país. Com efeito, o texto do art. 21, inciso X, da Carta Magna cuida de impor à União a obrigação de manter um serviço postal, mas não autoriza o entendimento de que tais serviços tenham se transformado em serviços públicos, na concepção técnica do termo. Muito ao revés, e significativamente, o texto do dispositivo constitucional em questão é inteiramente diferente daqueles, no mesmo artigo, nos quais a Constituição prevê a prestação de serviços públicos pela União Federal. Confira-se:

\section{“Art. 21. Compete à União: \\ (...) \\ $X$ - manter o serviço postal e o correio aéreo nacional; \\ $X I$ - explorar, diretamente ou mediante autorização, concessão ou permissão, os serviços de telecomunicaçōes, nos termos da lei, que disporá sobre a orga- niżação dos serviços, a criação de um órgão regulador e outros aspectos institucionais;}

XII. explorar, diretamente ou mediante autorização, concessão ou permissão:

a) os serviços de radiofusão sonora e de sons e imagens;

b) os serviços e instalações de energia elétrica e o aproveitamento energético dos cursos de água, em articulação com os Estados onde se situam os potenciais hidroenergéticos;

c) a navegaçāo aérea, aerospacial, e a infra-estrutura aeroportuária;

d) os serviços ferroviário e aquaviário entre os portos brasileiros e fronteiras nacionais, ou que transponham os limites do Estado ou Território;

e) os serviços de transporte rodoviário interestadual e internacional de passageiros;

f) os portos maritimos, fluviais e lacustres."

72. Do confronto entre os três incisos acima citados é possível concluir que, ao tratar de serviços públicos, a Carta Magna deixou expressa a possibilidade de a União Federal prestá-los diretamente ou mediante delegação de seu exercício aos particulares, em regime de concessão ou permissão. Tanto no caso do inciso XI, quanto no inciso XII, o legislador constituinte se vale da locução "explorar, diretamente ou

61 A Carta de $67 / 69$ também se referia ao serviço postal, rigorosamente nos mesmos termos que a atual (art. $8^{\circ}$, XI: Compete à União manter o serviço postal e o Correio Aéreo Nacional;). Lembre-se. porém, que ela permitia a monopolização pelo Estado de atividade econômica através de lei ordinária (art. 163). A lei, assim, era capaz de transformar uma exploração não monopolista sob regime concorrencial em monopolista (o que efetivamente ocorreu no caso do serviço postal, tanto com o Decreto-lei $n^{\circ} 509 / 69$, como com a Lei $n^{\circ} 6.538 / 78$ ), o que não é mais possivel na nova Constituição. 
mediante autorização, concessão ou permissão", deixando claro que todas as atividades arroladas nesses dispositivos são consideradas serviços públicos ${ }^{62}$.

73. Os serviços postais mereceram tratamento distinto. Além de ter previsto no art. $22, \mathrm{~V}$, a competência genérica da União para legislar sobre a matéria ${ }^{63}$, o constituinte tornou explícita a necessidade de esse mesmo ente "manter os serviços postais". É de se ver que, em lugar de outorgar competência ao Poder Público "para exploração direta ou mediante delegação", como fez no caso das telecomunicações (art. 21, XI, CF), a Constituição tão-somente impôs à União a obrigação de manter tal atividade ${ }^{64}$. Imaginar que o serviço postal é um serviço público, como os dos incisos XI e XII, seria ignorar a gritante diferença de texto que os distingue, como se o constituinte nada quisesse dizer com isso, e estivesse apenas fazendo uso diletante das formas linguiísticas, para dizer a mesma coisa de modos inteiramente diversos ${ }^{65}$.

74. Ademais, como já se viu, a exploração do serviço público, por caracterizar hipótese de intervenção estatal na ordem econômica, tem natureza excepcional e deve ser interpretada de forma estrita. Não é possível assim estender o sentido do verbo manter, que por si só não exclui a participação dos particulares nesse setor da economia, para que ele venha a abranger a prestação pelo Estado dessa atividade na qualidade de serviço público, com toda a restrição que essa forma de intervenção acarreta para o princípio da livre iniciativa. Se esta fosse a vontade do constituinte, ele teria se valido das mesmas expressões que utilizou no art. 21, XI e XII. A interpretação textual das disposições constitucionais sobre serviços postais também chancela o entendimento de que eles são meras atividades econômicas, e não serviços públicos.

75. Há ainda uma última razão que demonstra que os serviços postais não são serviços públicos por opção político-normativa, sendo explorados pelo Estado como modalidade de atividade econômica. A partir de 1988, a Empresa Brasileira de Correios e Telégrafos - ECT iniciou uma campanha de franqueamento de novas

62 Dinorá Adclaide Musetti Grotti, Teoria dos serviços públicos e sua rransformaçāo in Direito administrativo econômico, Coord. Carlos Ari Sundfeld, 2000, p. 65: “ (...) o art. 21, XI e XII, arrola os serviços que a União pode executar diretamente ou mediante autorização, concessão ou permissão, aí incluídos os serviços de (...)".

63 Fernando Herren Aguillar, Controle social de serviços públicos. 1999. p. 137. O autor faz o registro de que a competência legislativa conferida ao ente político não the dá o direito de explorar as atividades que hão de estar submetidas a tal regulamentação em regime de serviço público. $O$ ponto é por si evidente. Basta observar que compete à União legislar, e.g., sobre direito agrário e marítimo (art. 22, I), o que não transforma tais atividades em serviços públicos, mas apenas realiza a competência regulamentar prevista no art. 174 da Carta.

64 Celso Ribeiro Bastos e Ives Gandra Martins, Comentários à Constimição do Brasil, vol. III, 1992, p. 148: "O Serviço Postal Nacional cabe à União manter. Tal prestação de serviços não é exclusiva".

65 Vale fazer o registro de que parcela da doutrina inclui o serviço postal, um tanto acriticamente, no rol dos serviços públicos da União, juntamente com as atividades previstas nos incisos XI e XII do art. 21. Na boa parte dos casos, todavia, essa afirmação é incompatível com a fundamentação teórica exposta por esses próprios autores a respeito do serviço público. 
agências que se tornou notória, celebrando, para isso, uma série de contratos de exploração de serviços postais com as agências franqueadas.

76. Pois bem: se a prestação de serviço postal fosse considerada serviço público, jamais poderia ter havido o franqueamento de agências, por evidente violação do art. 175, da Constituição. Este artigo, como se sabe, exige concessão ou permissão, mediante prévia licitação, para que seja possível ao particular prestar qualquer serviço público. Se o serviço postal fosse serviço público, não poderia ter sido franqueado através de um simples contrato. $O$ entendimento da ECT, portanto, sempre foi de que sua atividade não constituía um serviço público, mas sim uma atividade econômica explorada pelo Estado por determinação constitucional ${ }^{66}$.

77. Vale fazer menção, nesse ponto, à Lei ${ }^{\circ} 9.648$, de $27 / 5 / 1998^{67}$, que passou a exigir fosse realizada licitação prévia para a exploração de serviços postais por particulares, e não mais apenas o contrato de franqueamento. Não se imagine, todavia, que a superveniência da lei em questão tenha produzido alguma alteração no que aqui se discute. Explica-se.

78. Embora às pessoas jurídicas de direito privado constituídas pelo Estado não se aplique, em geral, o regime jurídico público, algumas normas de direito público podem e devem ser por elas observadas, como se mencionou em item anterior. $O$ Superior Tribunal de Justiça e o Supremo Tribunal Federal já decidiram que as empresas públicas (como a ECT) e as sociedades de economia mista não só podem, como em determinados casos devem licitar, tendo em vista o princípio da impessoalidade que também lhes cabe observar ${ }^{68}$. $O$ fato de a lei passar a exigir prévia licitação para o franqueamento de agências da ECT não altera sua natureza, mas consiste em uma opção política do controlador da empresa, que é o governo federal.

79. Além disso, uma vez que a natureza do serviço postal é definida pela Constituição, se esta os houvesse considerado como serviços públicos, submetidos ao regime do art. 175 , a lei ordinária não poderia simplesmente validar - contra a Constituição - os atuais contratos, como o fez a Lei 9.648/98, já referida. Imaginar o serviço postal como serviço público acarretaria a invalidade de todos os contratos de franqueamento, bem como da lei no ponto em que teria pretendido validá-los.

66 Fernando Herren Aguillar, Controle social de serviços públicos, 1999, p. 138: “(...) se uma atividade puder ser desempenhada por particulares sem concessão ou permissão, ela não pode ser considerada serviço público."

67 A Lei 9.648/98 acrescentou parágrafo único ao art. $1^{\circ}$ da Lei 9.074 , de $07 / 07 / 1995$, com o seguinte teor: "Parágrafo único. Os atuais contratos de exploração de serviços postais celebrados pela Empresa Brasileira de Correios e Telégrafos - ECT com as Agências de Correio Franqueadas - ACF, permanecerão válidas pelo prazo necessário à realização dos levantamentos e avaliações indispensáveis à organização das licitações que precederão à delegação das concessões ou permissões que os substituirão, prazo esse que não poderá ser inferior a 31 de dezembro de 2001 e não poderá exceder a data limite de 31 de dezembro de 2002."

68 STJ, AGA 28633/RJ, Rel. Min. Sávio de Figueiredo Teixeira. DJ 29/11/93; Resp 84082/RS, Rel. Min. Demócrito Reinaldo, DJ 1/07/96; Resp 202157/PR. Rel. Min. Humberto Gomes de Barros; DJ 21/02/2000; e STF, RE 99.239-1/DF, Rel. Min. Neri da Silveira, DJ 8/10/85. 
80. Como se vê, em conclusão, o serviço postal não é serviço público, seja inerente, seja por opção político-normativa. Este era o entendimento da legislação ordinária anterior à Constituição de 1988, esta a interpretação adequada do art. 21 , $X$, da nova Carta, e esta também a compreensão da Administração Pública (ECT) e da legislação ordinária produzida posteriormente a 1988. Vale dizer: o presente estudo não subverte o conhecimento convencional, mas apenas sistematiza, com o embasamento doutrinário cabível, o que já se pratica de longa data, ainda que sem percepção clara.

\section{II.2. O serviço postal pode ser explorado por particulares, pois é atividade econômica não monopolizada}

81. Visto, assim, que os serviços postais não podem ser caracterizados como serviços públicos, chega-se à inevitável conclusão de que, atualmente, sua prestação pelo Poder Público configura meio de exploração de atividade econômica, o que, como regra, não impede que os particulares também a explorem concomitantemente, salvo a exceção da exploração monopolista legitimamente atribuída ao Estado. Cumpre, portanto, analisar se o serviço postal, embora explorado como atividade econômica e não serviço público, estaria submetido a um regime de monopólio.

82. Como já se teve a oportunidade de esclarecer, as hipóteses de reserva de monopólio estatal são situações absolutamente excepcionais, pois importam em negativa da liberdade de concorrência. Mais que isso, com a entrada em vigor da Constituição de 1988, apenas subsistem os monopólios que a nova Carta tenha consagrado. Com efeito, em um regime em que a livre iniciativa é princípio constitucional fundamental, só podem ser consideradas monopolizadas aquelas atividades que a própria Constituição expressamente assim considera. A análise a ser empreendida neste ponto é, portanto, bastante simples: cuida-se apenas de saber se a Constituição de 1988 considerou o serviço postal como atividade a ser explorada pela União em regime de monopólio. A resposta é negativa.

83. Como já se referiu, subsistem na Constituição apenas os monopólios previstos - de forma inequívoca, aliás - em seu art. 177, nos quais não se inclui qualquer menção ao serviço postal. Esse é o teor do dispositivo, in verbis:

"Art. 177. Constituem monopólio da União:

I - a pesquisa e a lavra de jazidas de petróleo e gás natural e outros hidrocarbonetos fluidos;

II - a refinação do petróleo nacional ou estrangeiro;

III - a importação e a exportação dos produtos e derivados básicos resultantes das atividades previstas nos incisos anteriores;

IV - o transporte marítimo do petróleo bruto de origem nacional ou de derivados básicos de petróleo produzidos no País, bem assim o transporte, por meio de conduto, de petróleo bruto, seus derivados e gás natural de qualquer origem; 
$V$ - a pesquisa, a lavra, o enriquecimento, o reprocessamento, a industrialização e o comércio de minérios e minerais nucleares e seus derivados."

84. Não é possível ao legislador ordinário ampliar o rol exaustivo de monopólios expressamente previstos na Constituição de 1988, da mesma forma como os monopólios anteriormente existentes, mas que não receberam a chancela da nova Carta - como o dos serviços postais -, não foram recepcionados pela ordem constitucional vigente, ainda que constituídos com fundamento em permissivo da Constituição anterior (art. 163, da Constituição de 1969) ${ }^{69}$.

85. Repita-se: em face do sistema instituído pela Carta de 1988, que assegura a livre iniciativa como fundamento do Estado brasileiro e enuncia, numerus clausus, os casos em que determinada atividade poderá ser subtraída da livre concorrência para ser explorada em regime de monopólio pelo Poder Público, as hipóteses criadas pela lei, anteriormente ao advento da nova ordem e não reproduzidas na Constituição Federal de 1988, não foram por ela recepcionadas.

86. Desse entendimento não discrepa a doutrina, como se constata da autorizada lição de Diogo de Figueiredo Moreira Neto:

"Finalmente, os institutos monopolistas estabelecem exceções plenas aos princípios do art. 170, caput $e$ inciso IV, transferindo da sociedade ao Estado a exploração de atividades econômicas específicas. É a eliminação total da concorrência e, em conseqüência, da definição do lucro pelos mecanismos de mercado. Distintamente da Carta de 1969, que também deixava em aberto, ao legislador ordinário, instituir monopólios (art. 163), a Constituição de 1988 restringiu a seis os monopólios estatais - petróleo (arts. 177, I, II, III e IV), energia nuclear (art. 177, V) e distribuição local de gás canalizado (art. 25, § $\left.2^{\circ}\right)$, sendo que os cinco primeiros, em favor da União e o sexto, dos Estados membros.

O Estado brasileiro ampliou, portanto, seus monopólios constitucionais mas, em compensação, com o desaparecimento da imprecisa regra do art. 163, caput, da Carta de 1969, tornou-se impossível, salvo em caso de Emenda à Constituição, a criação de qualquer outra modalidade." ${ }^{70}$

87. Desse modo, a prestação de serviços postais pelo Estado deve ser entendida como forma de exploração estatal de atividade econômica não monopolizada, o que significa que os particulares podem livremente desenvolver os serviços de entrega, recebimento, expedição e transporte de objetos de correspondências, valores ou encomendas, independentemente de ato de delegação prévia do Poder Público ${ }^{71}$.

64) Sobre o processo de filtragem da ordem infraconstitucional anterior pela nova Constituição, vejam-se: Luís Roberto Barroso, Interpretação e aplicação da Constituição. 1999, p. 49 e ss. e Paulo Ricardo Schier, Filtragem constitucional, 1999.

70) Diogo de Figueiredo Moreira Neto, A ordem econômica na Constituição de 1988, Revista de Direito da Procuradoria Geral do Estado do Rio de Janeiro n 42 , p.65. 
88. A natureza jurídica de atividade econômica não monopolizada também encontra amparo no próprio artigo $21, \mathrm{X}$, da Constituição Federal. Ao estabelecer que compete à União manter o serviço postal, a Carta Magna impôs que tal atividade seja obrigatoriamente exercida pelo Poder Público federal, tendo em vista a importância do serviço para a integração nacional, mas em nenhum momento afastou a possibilidade de que os particulares também a explorem, se assim lhes convier. Quis assegurar o mínimo e não impedir o mais. Entendimento diverso violaria toda a lógica da interpretação constitucional que, como já registrado, se orienta pela liberdade de iniciativa, e não pela intervenção estatal. A respeito do tema, Bulhões Pedreira observou com precisão, in verbis:

"O sentido da reserva ao Estado de determinada atividade econômica ou empresarial difere em função da natureza da ordem ou sistema econômico consagrado no plano constitucional: no sistema econômico liberal ou neoliberal, aquela reserva constitui exceção, porque nesses sistemas prevalecem os princípios da livre iniciativa e da competição econômica; já no sistema de economia centralizada, ou estatizada, a atuação do Estado na ordem econômica é princípio geral, dominante, e as regras permissivas de atuação do particular como agente econômico são exceções. Na primeira hipótese, a interpretação das regras sobre "monopólios" estatais há de ser restrita, porque são especiais; na segunda, há de ser irrestrita e abrangente, porque são gerais."72

II.3. Quanto à forma de atuação estatal o serviço postal é não monopolizado sob regime concorrencial; quanto à necessidade da atuação estatal. o serviço postal é obrigatório por expressa determinação constitucional.

89. Consolidando tudo que se expôs até aqui, convém classificar o serviço postal nas categorias apresentadas inicialmente.

90. Em primeiro lugar, o serviço postal é uma atividade econômica explorada pelo Estado, e não um serviço público. Quanto à forma de atuação estatal. já referida, o serviço postal só pode ser explorado de maneira não monopolizada e sob regime concorrencial. Com relação a este último aspecto. lembre-se que o regime não concorrencial só pode ser adotado pelo Estado se assim autorizado de modo específico pela Constituição, uma vez que constitui exceção ao seu art. 173. Não há, em toda a Carta, qualquer menção que excepcione o serviço postal da obediência a este dispositivo, de modo que sua exploração deverá se dar em condições concorrenciais.

91. Por fim, quanto à necessidade da atuação estatal, o serviço postal é obrigatório, por força de previsão constitucional. Como já se mencionou, o constituinte

71 O que não afasta a competência da Uniāo para regular e normatizar o setor, com tundamento nos arts. 22, V, e 174 da Constituição.

72 Bulhões Pedreira, Monopólio-gás (parecer), Revista Trimestral de Direito Público, $\mathrm{n}^{\circ}$ 101. p. 38. 
originário entendeu haver relevante interesse público ou imperativo de segurança nacional (art. 173) em que a União mantivesse continuamente um serviço postal, à parte dos serviços privados que possam existir. A idéia, bastante evidente e implementada também em outros países, decorre de uma percepção histórica da atividade postal como de fundamental importância para as comunicações do país. Embora essa realidade já tenha sido substancialmente alterada, com o advento das comunicações eletrônicas, deseja a Constituição que a União tenha sempre um serviço postal reserva em operação, evitando-se dificuldades maiores na hipótese de os particulares, por qualquer razão, deixarem de explorar a atividade.

\section{SITUAÇÃO CONSTITUCIONAL DA EMPRESA BRASILEIRA DE CORREIOS E TELÉGRAFOS - EBCT. A Constituição de 1988 não recepcionou o monopólio legal da Lei no 6.538/78. A EBCT desempenha atividade econômica constitucionalmente obrigatória $(C F$, art. $21, X)$, não monopolizada e em regime concorrencial.}

92. Aplicando tudo que se expôs até aqui ao caso concreto, resta apenas avaliar a situação da Empresa Brasileira de Correios e Telégrafos - EBCT. A EBCT foi criada pelo Decreto-lei 509/69 (a essa altura ECT), a fim de "executar e controlar, em regime de monopólio, os serviços postais brasileiros" (art. $\left.2^{\circ}\right)^{73}$. A Lei 6.538, de $22 / 6 / 1978$, que regulou direitos e obrigações concernentes ao serviço postal, não alterou tal regime de exploração de atividade econômica, que continuou a ser monopolista $\left(\operatorname{art} .9^{\circ}\right)^{74}$.

93. O advento, porém, da Constituição de 1988 - que, como se viu, prevê um elenco exaustivo de atividades monopolizadas - não mais permite falar-se em monopólio dos serviços postais. Desse modo, as leis anteriormente referidas não foram recepcionadas pela Carta vigente, no que tange à instituição do monopólio.

94. À Empresa Brasileira de Correios e Telégrafos cabe, assim, em face da nova ordem constitucional, desenvolver a atividade econômica de prestação de serviços postais, na forma do disposto no art. 21 , X, da Constituição Federal, em regime não monopolista e concorrencial, sendo livre à iniciativa privada a exploração dos serviços postais desde 5 de outubro de 1988.

73 “Art.2 - À ECT compete: I - executar e controlar, em regime de monopólio, os serviços postais em todo o território nacional; II - exercer, nas condições estabelecidas nos arts.15 e 16 , as atividades ali definidas."

74 "Art. $9^{\circ}$. São exploradas pela União, em regime de monopólio, as seguintes atividades postais: I - recebimento, transporte e entrega, no território nacional e expedição, para o exterior, de carta e cartão postal; II - recebimento, transporte e entrega, no território nacional, e a expedição, para o exterior, de correspondência agrupada; III - fabricação, emissão de selos e de outras fórmulas de franqueamento postal." 


\section{CONCLUSÕES}

1. O presente parecer foi desenvolvido sobre as formulações doutrinárias a seguir resumidas:

A. A interpretação jurídica deve voltar-se para a realização dos princípios constitucionais, que são as normas que espelham a ideologia da Constituição, suas premissas básicas e seus fins. O constituinte de 1988 elegeu a livre iniciativa como fundamento do Estado brasileiro e como princípio específico da ordem econômica. Nessa linha, ponderados, naturalmente, eventuais valores contrapostos, devem ser prestigiados na interpretação constitucional os postulados que realizam o princípio da livre iniciativa, como a liberdade de empresa, a livre concorrência e a liberdade de contratar.

B. A atuação direta do Estado na ordem econômica pode dar-se (i) pela prestação de serviços públicos e (ii) pela exploração de atividade econômica. Os pressupostos e o regime constitucional de cada uma dessas modalidades de intervenção estatal são diversos.

C. O conteúdo material do que seja serviço público varia em razão do momento, do lugar e, por vezes, dependerá de uma opção política. Classificam-se, assim, os serviços públicos em (i) inerentes, que são aqueles ligados ontologicamente às funções típicas do Estado e que involvem o seu poder de império; e (ii) por opção político-constitucional, que são aqueles que abrigam atividades tipicamente econômicas, mas que em razão de sua relevância ou outras considerações de interesse público, foram definidos por norma jurídica como serviço público.

D. A exploração de atividade econômica pelo Estado deve dar-se em caráter excepcional e subsidiário, em reverência ao princípio constitucional da livre iniciativa. Quanto à forma de atuação, poderá ser (i) monopolizada e (ii) não monopolizada, sob regime concorrencial. Quanto à necessidade da atuação estatal, poderá ser (i) obrigatória, por disposição constitucional expressa ou (ii) facultativa, por opção legislativa.

2. Em desfecho desse estudo, que se fez inevitavelmente longo, é possivel compendiar suas principais conclusões nas seguintes proposições objetivas:

A. O serviço postal não é um serviço público, ainda que possa ter tido tal natureza nos primórdios de sua implantação. Trata-se de uma atividade econômica e como tal tem sido tratado no direito brasileiro, pelo menos desde o regime constitucional anterior.

B. O serviço postal é uma atividade econômica obrigatória para o Estado, por força de mandamento constitucional, mas desenvolvida em regime concorrencial. De fato, a Constituição de 1988 só tolera os monopólios por ela instituídos e, dentre eles, não se encontra o serviço postal. Lei anterior à Carta em vigor e que dispunha em sentido diverso não foi recepcionada, consoante regra elementar de direito intertemporal. 
C. À Empresa Brasileira de Correios e Telégrafos - EBCT, controlada pela União, cabe a prestação de serviços postais, não podendo demitir-se o Poder Público do desempenho dessa atividade. Nada obstante, à luz da Constituição e da legislação validamente em vigor, é livre à iniciativa privada o desempenho da atividade econômica de exploração dos serviços postais.

É como me parece. 